\title{
THE WORK OF THE WISCONSIN HISTORICAL SOCIETY;
}

\section{BY REUBEN GOLD THWAITES, SECRETARY.}

Wisconsin had an historical society while it was still in the Territorial stage. As the result of agitation begun in the columns of the Mineral Point Democrat, in October, 1845-three years before Wisconsin was admitted to the Union-a society was formed at Madison, the capital, in October, 1846, by delegates in attendance on the first constitutional convention. Most of the principal men of the Territory were present at the initial meeting of the association, the purpose of which was "to collect from the pioneers then" alive, such facts in regard to the early history of Wisconsin as they might possess, as well as to treasure up those concerning the future."

But while the enthusiasm at this meeting was great, the participants were immersed in their own affairs and no one gave the matter any further attention; no records were kept, no money was paid into the treasury, no work was performed. What was everybody's business, was nobody's. Thus the first organization of the society may be considered as having died when the gavel sounded for adjournment.

On the thirtieth of January, 1849 , nineteen days after the opening of the first session of the State Legislature in Madison, a hundred and fifty persons, chiefly members of the Legislature, held a meeting at the American House and formed a State Historical Society, the previous existence of the old society, now defunct, being ignored. Governor Nelson Dewey was chosen President of the Society, as a compliment to his official station. The list of vice-presidents comprised one from each county in the State. I. A. Lapham, the distinguished scientist and antiquarian, was elected Secretary, but he was able to give no time to the work. Public addresses were given before the Society, in 1849,1850 , and 1851 , by prominent citizens of the State; but beyond these three ad- 
dresses, nothing of importance was done during this period. The pamphlet discourses were sent ont to perhaps a dozen other learned societies, and a library of fifty volumes was slowly accumulated-all of these books being state laws, legislative journals, miscellaneous public documents, two volumes of the "Transactions of the American Ethnological Society" and a volume of American bibliography. The meagre collection was contained in a small glass-faced case, kept on a table in a corner of the Governor's office, and this case is now exhibited as a curiosity in the Society's museum.

It was evident that the Society would never amount to anything at this rate of progress. Somebody must devote his entire time to the work, becoming personally responsible for the conduct of the Society's affairs, and giving to it life and individual character. The man for the place was imported to Madison in October, 1852. He was Lyman C. Draper, of Philadelphia, who had already spent about fifteen yenrs in the accumulation of materials for Western history: achieving such success in his manuscript and book collections, in a time when collectors of Americana were few, as to attract the attention of scholars throughout the Eastern States. Draper was then thirty-seven years of age; full of vigor and push, kindly of disposition, persuasive in argument, devoted to his life-task of collecting, self-denying in the cause, and of unimpeachable character.

For various reasons, not necessary here to recite, it was the eighteenth of January, 1854, before the Society was thoroughly reorganized for work on the new plan. Draper was at that time chosen Secretary and at once entered with joyous enthusiasm upon the undertaking of accumulating books for the library, relics and curiosities for the museum, portraits for the gallery, and documents for publication in the Wisconsin Historical Collections. In the course of a few weeks, the little library case was too small. By the close of the year, the Secretary was able to report to the Society the acquisition of a thousand volumes and a thousand pamphlets and documents-certainly a remarkable showing, compared with the 
fifty books which had been the product of the five years preceding his administration. For want of library space, the greater part of the acquisitions were stored in Draper's residence until in August, 1855, a small room in the corner of the basement of the local Baptist church was secured for the Society's use. On the first of January, 1856, Daniel S. Durrie, a bookseller, formerly in business at Albany, N. Y., was chosen Librarian, and held this useful and honorable position for over thirty-six years until his death, August 30 , 1892. He was succeeded by Isaac S. Bradley, for seventeen years his chief assistant.

The Society soon securing legislative aid, the collections grew apace until nearly the entire basement of the church was. occupied. This place was, however, dark, damp and dingy, and in no way suited to library purposes. In January, 1866, the institution-library, portrait gallery and museum-was removed by authority of the Legislature to quarters especially prepared for it in the then new south wing of the capitol. It was thought that there was now ample room for the accessions of at least a quarter of a century. But such was the rate of increase that in less than ten years time these quarters were a tight fit. By 1881 cords of volumes, pamphlets, and relics. were piled in out-of-the-way corners and rooms throughout the capitol, there being no space to shelve or display them.

Secretary Draper, as the executive officer of the Society, now opened a vigorous campaign for a new building; he awakened interest in many of the leading men of the State, and gained the unanimous support of the newspaper editors. But there were certain complications which made it impossible to carry a separate building scheme through the Legislature. A compromise resulted in the Society being given the second, third, and fourth floors of one of two large transverse wings ordered by the Legislature of 1881 to be attached to the capitol. In December, 1864, the transfer was made to the new and greatly enlarged quarters - the library occupying the second and third floors of the wing; and the museum and portrait gallery the fourth. These several floors are reached by a 
THE WORK OF THE. WISCONSIN HISTORICAL SOCIETY. 261

passenger elevator. Having seen the Society established in its new rooms, Secretary Draper resigned his position on the sixth of January, 1887, with a record of thirty-three years of arduous labor in behalf of the State.*. It was Dr. Draper's desire to devote the remainder of his life to forwarding some private literary work, but he was prevented by ill-health from accomplishing his long-cherished plans in this direction, and died on the twenty-sixth of Angust, 1891. The Wisconsin Historical Library, which he practically founded, and so successfully managed and purveyed for through a third of a century, will remain an enduring monument to his tireless energy as a collector of Americana; while the first ten volumes of Wisconsin Historical Collections attest to his quality as an editor of material for Western history. ${ }^{\dagger}$

From the first, the Wisconsin Legislature, with enlightened liberality, looked kindly on the undertaking, and made appropriations with which to purchase accessions, meet the greater part of the running expenses, and pay the salaries of Secretary and Librarian. The relationship of the Society to the State is not generally understood, even in Wisconsin. It is, however, easy of comprehension. By statute, the Society, which operates under a legislative charter granted in 1853 , is the trustee of the State, and holds all of its property for the Common. wealth. It can neither sell nor give away any of the property it thus holds in trust, nor remove any of it from the capitol, without special consent of the Legislature. As to rooms, lights, fires, janitorial service, repairs, mechanical supplies, stationery, printing, and postage, the Society is on pretty much the same footing as any of the State bureaus. The machinery of the Society serves to remove the management of this enterprise from partisan control; the members are gentlemen of prominence throughout the State, of all shades of political opinion, and for forty-three years there has not been even a suspicion of "politics" in. the conduct of its af-

*He was succeeded by the writer of this paper, Mr. Thwaites, who had been the Assistant Secretary for two years previous.-ED.

tSeo Wisconsin Historical Collections, Vol. XII, pp. 1-22, for Secretary Thwaites's memoirs of Dr. Draper. 
fairs. The Historical Society is an institution which all good. citizens unite in declaring should be free from such baneful. influences. The work is thus left in the hands of those having a keen interest in it, and trained to its performance. As. for the official interests of the Commonwealth, they are looked. after by the Governor, Secretary of State, and State Treasurer, who are by law ex officio members of the Executive. Committee and serve on its most important sub-committees. The fact that these officers have the power to report upon the Society's operations, and the further fact that the Legislature. can at any time investigate its affairs, tend to make the management scrupulously careful.

The Society is actively engaged in several departments of research and accumulation, has a fairly equipped historical. and ethnographical museum, and a portrait gallery of Wisconsin worthies, containing about two hundred portraits in oil, about a hundred crayons, and numerous pieces of portrait. statuary. About fifty thousand persons visit the gallery and. museum annually, the three large halls devoted to these departments being possibly the best patronized exhibition. rooms in the State. Yet, whatever reputation the Society. may have won among scholars has been chiefly the outgrowth. of its library; in this it takes great interest and is doing its. best educational work.

In 1875 the miscellaneous books in the State Library, at. the other end of the capitol, were transferred, by order of the Legislature, to the Historical Society's library, leaving the former purely a State law library, under the control of the Justices of the Supreme Court; while the latter became, to. all intents and purposes, a miscellaneous State Library in charge of the Historical Society. The relations between the two libraries, both the property of the Commonwealth, are harmonious.

The Society has published twelve volumes of Wisconsin Historical Collections, averaging five hundred pages each; the Catalogue of its library, in seven volumes of seven to. eight hundred pages each; the Proceedings of its annual 
THE WORK OF THE WISCONSIN HISTORICAL SOCIETY. 263

meetings; two Special Class Catalogues, one containing titles of "Books on the United States Civil War and Slavery," and the other an exhaustive "Bibliography of Wisconsin Authorship;" three editions of its Portrait Gallery Catalogue, and numerous bistorical pamphlets.

The Wisconsin Historical Library now numbers about 95,000 volumes and 75,000 pamphlets. The average annual increase is 3,500 volumes and 3,000 pamphlets; nearly twothirds of the former are purchased, but not over ten per cent of the latter.

In the West, large private libraries are not so numerous as in the East, and these are generally in the possession of young or middle-aged men. Thus we have not that source of supply enjoyed by the older libraries of the Atlantic slope, in the receipt of books by bequest. Only once have we had a large gift of this character. In 1866, Mrs. Otto Tank, of Fort Howard, gave us the library of her father, a scholarly Amsterdam clergyman named Van der Meulen. The Tank Library consists of 5,000 old and rare volumes, mostly in the Dutch language - probably the largest collection of Dutch books in the United States. Nearly half of them are richly bound in vellum, and many are profusely illustrated with seventeenth century copperplate engravings; in the collection are numerous Bibles, atlases and charts, old editions of the classics, early lexicons and historical works. These old Dutch books are among the most precious of our treasures.

The principal daily and weekly newspapers of the State, some three hundred and seventy-five in number, are sent gratis to the library, by their publishers, for binding and permanent preservation. Some two hundred and fifty stout volumes are annually marle up in this manner; three years of the smaller weeklies being bound in a volume. These files generally reach back to the first issues of the journals represented. We find that the State papers are frequently referred to by judges, lawyers, members of the Legislature, and special investigators of every sort, while, as the Society's files are in many cases the only full ones in existence, editors themselves have not 
seldom had occasion to examine them in the library or write for data contained in early issues. Our collection of bound newspaper files published oitside the State, amounts to over 7,000 volumes. The earliest London file. is that of the Public Intelligencer, bearing date 1656. From that time on, there are few years not represented by some prominent English or American journal. From 1750 forward the collection is unusually strong, especially in the American department. Newspapers are a fertile source of historical information, and this feature of the library we regard as of the utmost practical importance. An elaborate catalogue of our newspaper files is now being prepared for publication.

Regarding the scope of the Society's library, I may explain that it is a general reference library, with the lines of local and general American and English history, economics, and description, developed with especial care. On account of the proximity of the University of Wisconsin-a mile awayabout ninety per cent of our readers are students from that institution, and in purveying for the State Historical Library their wants are taken into consideration. University students doing original work of some importance are under certain restrictions allowed access to our shelves, the same as other special investigators, as it is greatly to their advantage to have in sight all the resources of the library on a given subject. To be as useful as possible is the aim of the library, and the attendants are instructed to grant to deserving students whatever privileges are consistent with careful management. The University seminars, and some special classes in that line of work, are given the use of rooms adjoining the library. The students and professors are in fact, encouraged to use our library as freely as they would that of the University itself. The University library, of some 30,000 volumes, is at present more especially devoted to technical works, and duplication of books already in the State Historical Library is avoided so far as possible; the students appear chiefly to rely upon the latter, as their own literary laboratory.

In addition to the University students, specialists from all 
parts of the West may be found in the State Historical Library, especially in the summer months. During the past year historical investigators from several of the Atlantic States, north and south, have sought our shelves chiefly to consult -our manuscript collection, which now embraces nearly six hundred stout folio volumes. These are particularly rich in material for the history of the West and the South during the Revolutionary War, and the war of $1812-15$, and for the history of the fur trade in the Old Northwest.

The Legislature has certainly been generous to the Society; with a few notable exceptions, the latter's relations with the governing body have been harmonious, and it must be confessed that the Society could not have been successfully maintained in this State-far removed from the intellectual centers of the Nation, and thereby laboring under pecculiar difficulties-without liberal State aid. The most immediate need of the Society is a new, commodious, fire-proof building, designed on the most approved models, and costing not less than $\$ 400,000$. The present quarters in the State capitol are quite inadequate in extent, badly constructed in every way, and in no sense fire-proof; moreover, the State Government needs for the use of legislative clerks and committees the space occupied by the Society. At the next meeting of the Legislature, in 1895 , we shall stoutly urge our necessities in this regard, and have good reason to hope that they will be recognized in the same spirit of liberality that has hith. erto marked the attitude of the State toward this now important factor in its system of public education. 
Copyright of Annals of Iowa is the property of State of Iowa, by \& through the State Historical Society of Iowa and its content may not be copied or emailed to multiple sites or posted to a listserv without the copyright holder's express written permission. However, users may print, download, or email articles for individual use. 